Original Research paper

\title{
Application of a Developed Dispersion Model to Port of Brisbane
}

\author{
${ }^{1}$ Sanaz Jahangiri, ${ }^{1,2}$ Natalia Nikolova and ${ }^{1,2}$ Kiril Tenekedjiev \\ ${ }^{1}$ Australian Maritime College, University of Tasmania, Launceston, Tasmania, Australia \\ ${ }^{2}$ Nikola Vaptsarov Naval Academy - Varna, Bulgaria
}

Article history

Received: 10-07-2018

Revised: 29-08-2018

Accepted: 10-10-2018

Coressponding Author:

Sanaz Jahangiri

Australian Maritime College,

University of Tasmania,

Launceston, Tasmania,

Australia

Email: sanaz.jahangiri@utas.edu.au

\begin{abstract}
The emissions from vessels utilising heavy fuel oil include large amounts of nitrogen oxides, sulphur dioxide and particulate matter, presenting significant health risks to people living near ports. To determine the effect of these emissions on human health, complex atmospheric dispersion modelling using CALPUFF assesses ground-level concentrations at receptors surrounding the sources. This paper demonstrates the application of the methodology by applying it to Port of Brisbane for the full 2013 calendar year. Various Health impact assessments as well as carcinogenic and ecological effects are discussed in depth. Results reveal that with the imminent development of many Australian ports, there is a need for continual monitoring of emissions caused by shipping.
\end{abstract}

Keywords: Shipping, Health Risk, Emission Inventory, Dispersion Modelling

\section{Introduction}

It is widely agreed that shipping exhaust emissions are a significant source of air pollution (Corbett et al., 1999; Cooper, 2003). The three largest and most worrisome are Nitrogen Oxides $\left(\mathrm{NO}_{\mathrm{x}}\right)$, Sulphur Oxides $\left(\mathrm{SO}_{\mathrm{x}}\right)$ and particulate matter $(\mathrm{PM})$. Implementing the amendments to the MARPOL Annex VI regulations is intended to reduce shipping emissions worldwide (Hughes, 2011), but this is not easy because their effects tend to be dispersed and difficult to track to source.

In-port emissions, although a relatively small proportion of total emissions, have significant health impacts on nearby populations (Corbett et al., 1999) and are linked to cardiopulmonary- and cancer-related health problems. Winebrake et al. (2009), for instance, estimated that in 2012, $\mathrm{SO}_{\mathrm{x}}$ emissions from shipping were implicated in approximately 87,000 deaths worldwide. Studies in Australia have considered total emissions both within coastal waters (Goldsworthy and Goldsworthy, 2015) and in a specific port (Goldsworthy and Renilson, 2013), but have not yet quantified their dispersion and deposition across local populations. This paper presents the methodology to obtain emissions concentrations within Australian ports in general and in a case study of Port of Brisbane in particular. It is based on a comprehensive inventory of vessel emissions in Port of Brisbane over a year, using actual vessel movements and applies atmospheric dispersion modelling to this quantified data to predict the ground-level concentrations of gaseous pollutants and the deposition of particulate matter, based on local meteorological and geographical conditions. On the final stage, assessing each resulting emission concentration for its individual health impact, based on a calculated risk values for each concentration has been also identified.

\section{Port Overview}

Port of Brisbane is a multi-modal port on the Brisbane River on the east coast of Australia, currently managing 29 operational berths. There are also a number of privately managed berths: Fisherman Islands, at the mouth of the Brisbane River, hosts twelve container berths, a number of bulk product berths and one general purpose berth; and more dry- and wet-bulk terminals are sited up-river towards Hamilton Reach, where a cruise terminal and naval base are located (PB, 2015). The port is unique because of the long distance between the outer port limit and the berths on the river: A channel of $82.9 \mathrm{~km}$ to the entrance beacons is located approximately seven kilometres seaward of the outermost berth on Fisherman Islands; a map of this approach appears in Fig. 1. The port boundary extends from the pilot boarding ground at the north to the lowest reaches of the Brisbane River in the south and is defined by Moreton Island to the east and the Australian mainland to the west. 


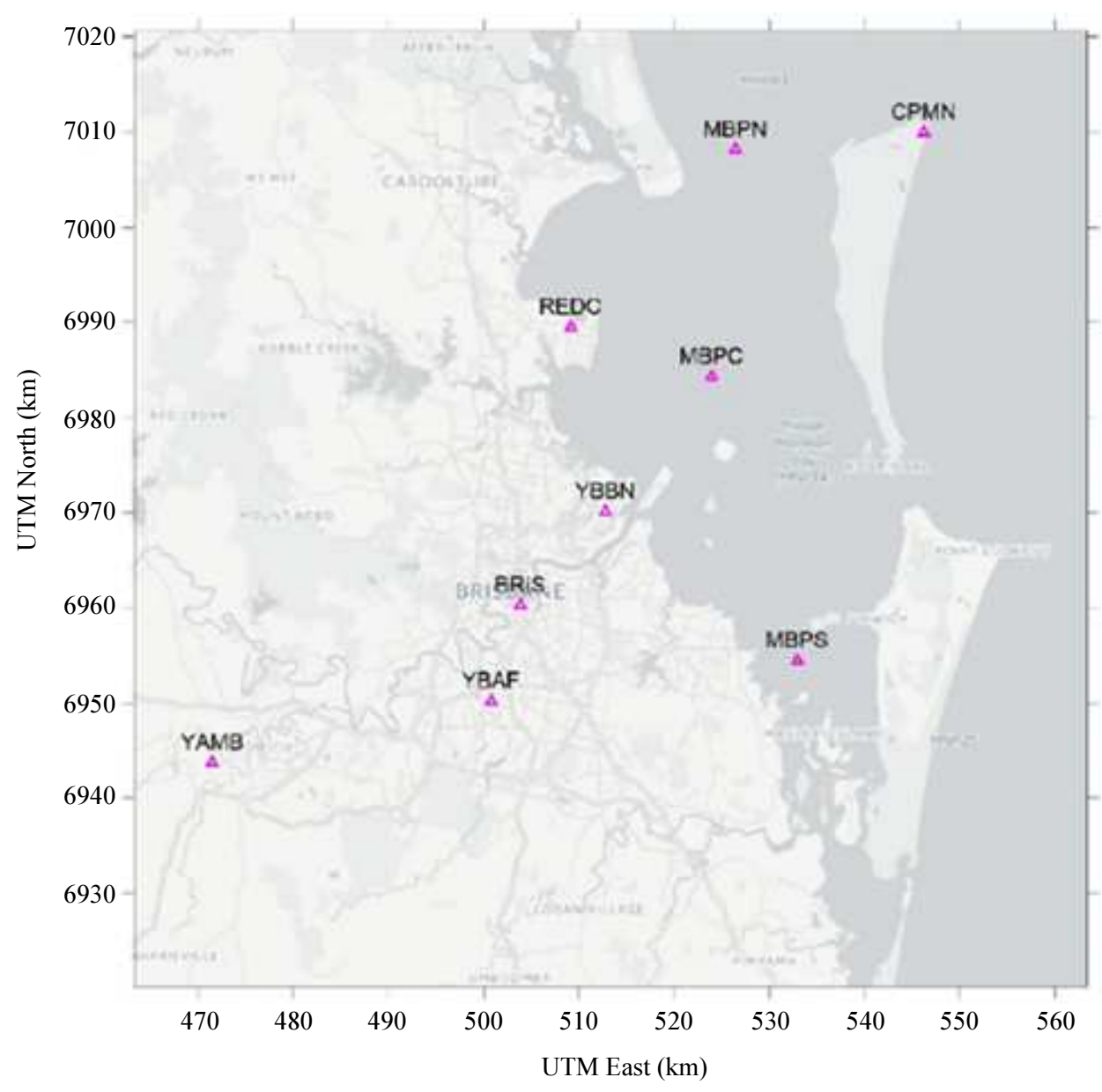

Fig. 1: Port of Brisbane area including the approach from the pilot boarding ground and Surface meteorology stations used in the CALPUFF model

Pilots join the vessels at the pilot boarding ground at the outer port limit, near Caloundra Heads. Vessels then move to the entrance beacon under their own power, typically at a speed close to normal cruising. At the entrance beacons, most are assisted by tugs to their destination berth. During this final leg, vessels travel at a restricted speed dictated by their draft and under-keel clearance. Occasionally vessels may hold fast at the shipto-ship transfer anchorages near the entrance beacons until a berth becomes available. Once at berth, they load and offload cargo and supplies as required. Some may reposition to another berth during their call at the port, depending on the types of cargo they are handling.

Upon departure, vessels are assisted by tugs to manoeuvre out of the berth and, depending on their length, to move some distance towards the entrance beacons. Some need to wait for suitable tidal movements before proceeding down-river and through the channel. They go under their own power to the pilot boarding ground, where the pilot disembarks and the vessel goes on its way. Departure transits usually take less time than arrivals.

\section{Atmospheric Dispersion Modelling}

A number of dispersion models exist, depending on the size and complexity of the domain and the type of pollutant source. The Good Practice Guide for Atmospheric Dispersion Modelling compiled by the New Zealand EPA (Bluett et al., 2004) provides a solid review of the range of dispersion modelling techniques and their applicability. Similar studies have been undertaken by both the NSW EPA (2005) and the USEPA (Holmes and Morawska, 2006). All agree that atmospheric modelling of coastal regions provides a challenge, given the complex meteorological conditions they present. Modelling is further hampered by the irregular geographical features of many coastlines. Bluett et al. (2004) question the ability of simple Gaussian-plume models in these conditions and suggests the need to use more advanced puff or Lagrangian-based models. A number of more advanced dispersion models have been developed to overcome the shortcomings of steady-state Gaussian-plume models (Scire et al., 2000a; 2000b). The CALPUFF modelling 
system is one of the most commonly used alternatives, modelling the pollutants as 'puffs' of matter emitted from the sources. The nature of puff modelling means it is time dependent and capable of predicting emissions over long ranges $(>50 \mathrm{~km})$. This also means it is capable of dealing with complex terrains and meteorological conditions, making it suitable for coastal regions and areas with widely varying wind conditions. The downside of this is the increased input data required.

\section{Materials and Methods}

\section{Vessel Emissions Inventory}

To measure the emission rates of the key pollutants, as well as the fuel consumption and greenhouse gas emissions of Ocean Going Vessels (OGVs) within the port, a detailed emissions inventory model was constructed. Being applied to Port of Brisbane for a fiveyear period, this methodology is then applicable to most ports or wider coastal regions. Harbour craft (including tugs and ferries) were not included in the inventory as studies have shown that compared to OGVs, their emissions are of minor importance (Jalkanen et al., 2009; Lucialli et al., 2007).

Vessel movement data was obtained from records collected by Port of Brisbane. The five-year dataset, from 2010 to 2014, included identification of individual vessels, their type and the time at which they reached the pilot boarding ground, their destination berths and times of departure (Clarkson, 2015). No information indicated the time at which a vessel passed a key transit mark such as the entrance beacons when entering or departing port. When a vessel was placed at anchor during some part of its call to the port, two separate entries were made: The first listed the anchorage as the destination port and the second listed the actual destination port. Data for vessels repositioning during a call were recorded in the same manner. A large number of anomalies in the data relate to multiple berth visits or those involving anchorage and arrival or departure times are often incomplete or highly erratic. For consistency, such records were discarded: A total of 1268 records $(9 \%)$ over the five years.

During a visit to the port, vessels undertake a number of movements and each is assigned a single operating mode. Vessels are 'in transit' for most of both the inbound and outbound passages, from the pilot boarding ground to berth and vice-versa. The average speed of the vessel while in transit was calculated from the times recorded in the dataset and the known distance of each transit. While it is known that vessels slowed at the entrance beacons to be assisted by tugs, nothing in the data indicated the time spent in the restricted speed zone. To overcome these limitations, two approaches are taken: First, the restricted speed zone is disregarded and the complete inward and outward voyages are treated as transiting; and second, an approximate time taken to travel from the entrance beacons to the berth is reached by looking at a limited set of automatic identification system data. It was then concluded that in general the times were relatively similar regardless of the vessel type or size and one hour for the inbound voyage and half an hour for the outbound voyage were typical.

A separate operating mode was assigned to a vessel at berth and the time spent at berth was recorded in the original data set. Time taken to dock and un-dock was included as transit time, with arrival and departure times recorded as the time that the first (or last) mooring line was secured (or released). Although the methodology provides for the inclusion both of vessels at anchor and those manoeuvring between berths, these are not included in the case study because most were unreliable entries and were thus excluded.

During the period of interest 2935 unique vessels visited the port, each categorised as one of 32 different types (Clarkson, 2015). For the purpose of the emission inventory, many of these types were similar or the same in terms of operating and engine characteristics and are re-categorised into eleven standard categories, shown in Table 1.

Only one vessel was classed as 'miscellaneous' in the supplied data. This was an auto carrier and it is denoted as such in the redefined categories. One vessel was described as a passenger/general cargo ship, but was in fact a passenger cruise ship. In the data supplied, many self-discharging bulk carriers were incorrectly labelled as bulk/oil carriers. It has been suggested by Star crest (SCG, 2005) that self-discharging bulk carriers have higher berthed emissions, caused by their auxiliary unloading equipment; in this study, all bulk carriers are assigned to one category.

In addition to the OGVs, 30 yachts, 16 dredgers and a number of barges and tugs (fewer than 100) were captured in the dataset. These are deemed irrelevant as they are not OGVs and are consequently are omitted from the emissions inventory. The dredge and tug data were sporadic and did not represent the entire dredge and tug activities within the port and are also omitted.

For each vessel type, default engine powers (both main and auxiliary) are assigned as well as average service speeds, sourced from the USEPA (2009) and based on surveys conducted in nine US ports. The problem with using such values is that they do not consider the size of individual vessels, so the average size of the vessels visiting the ports surveyed has the greatest bearing on the averaged main engine powers; the averaged service speeds and auxiliary engine powers are also affected (Clarkson, 2015). The default vessel values are shown in Table 2 . The power ratios between the auxiliary and main engines exhibit strong correlation with those suggested by other studies (Goldsworthy and Renilson, 2013; SCG, 2005). 
Table 1: Classifications of vessels based upon the supplied vessel type

\begin{tabular}{|c|c|c|c|}
\hline Defined vessel types & Data supplied vessel types & Defined vessel type & Data Supplied vessel types \\
\hline Auto Carrier & $\begin{array}{l}\text { miscellaneous class vehicle } \\
\text { Carrier }\end{array}$ & Ro-ro & $\begin{array}{l}\text { Landing craft } \\
\text { Passenger/ro-ro cargo ship } \\
\text { Ro-ro cargo ship }\end{array}$ \\
\hline Bulk Carrier & $\begin{array}{l}\text { Bulk/oil carrier } \\
\text { Bulk carrier } \\
\text { Cement carrier } \\
\text { Self-discharging bulk carrier } \\
\text { Woodchip carrier }\end{array}$ & Tanker & $\begin{array}{l}\text { Chemical/oil products tanker } \\
\text { Chemical tanker } \\
\text { Crude oil tanker } \\
\text { Lpg tanker } \\
\text { Oil products tanker }\end{array}$ \\
\hline Container Ship & Container ship & Navy vessel & Naval ship \\
\hline $\begin{array}{l}\text { Cruise Ship } \\
\text { General Cargo ship }\end{array}$ & $\begin{array}{l}\text { Passenger/general cargo ship } \\
\text { Passenger cruise ship } \\
\text { general cargo ship }\end{array}$ & Reefer & Refrigerated cargo ship \\
\hline & Livestock carrier & Not applicable & $\begin{array}{l}\text { Barge } \\
\text { Barge carrier dredger }\end{array}$ \\
\hline Miscellaneous & $\begin{array}{l}\text { Fishing vessel } \\
\text { Heavy load carrier } \\
\text { Research ship } \\
\text { Trawler }\end{array}$ & & $\begin{array}{l}\text { Tug } \\
\text { Yacht }\end{array}$ \\
\hline
\end{tabular}

Table 2: Averaged vessel specifics based on vessel type

\begin{tabular}{llllllr}
\hline $\begin{array}{l}\text { Defined } \\
\text { vessel types }\end{array}$ & $\begin{array}{l}\text { Main } \\
\text { engine type }\end{array}$ & $\begin{array}{l}\text { Average service } \\
\text { speed(knots) }\end{array}$ & $\begin{array}{l}\text { Average main } \\
\text { engine power (kW) }\end{array}$ & $\begin{array}{l}\text { Average aux } \\
\text { engine power (kW) }\end{array}$ & $\begin{array}{l}\text { Average boiler } \\
\text { power (kW) RSZ }\end{array}$ & Hotel \\
\hline Auto Carrier & SSD & 18.8 & 11,155 & 2,967 & 371 & 371 \\
Bulk Carrier & SSD & 14.5 & 8,350 & 2,854 & 109 & 109 \\
Container Ship & SSD & 21.9 & 26,122 & 5,747 & 506 & 506 \\
Cruise Ship & MSD & 21.1 & 27,357 & 7,605 & 750 & 750 \\
General Cargo Ship & SSD & 15.3 & 6,709 & 1,738 & 06 & 106 \\
Miscellaneous & MSD & 12.7 & 9,564 & 2,573 & 750 & 0 \\
Navy Vessel & MSD & 21.1 & 27,357 & 7,605 & 464 & 750 \\
Reefer & SSD & 19.7 & 10,060 & 4,084 & 109 & 164 \\
RO-RO & MSD & 16.0 & 11,687 & 3,027 & 371 & 371 \\
Tanker & SSD & 14.7 & 9,667 & 2,040 & & 09 \\
\hline
\end{tabular}

The calculation of the main and auxiliary engines is done separately. As such, during each mode, the main engine load factor is usually based on the propeller relationship law, which according to Browning and Bailey (2006), is Equation one. However, a correction of 0.83 is added to compensate the assumptions that vessels do not function at 100 percent MCR service speed (USEPA, 2009); USEPA suggests that its supplied cruise speeds are approximately 0.94 of the service or maximum speed.

As no information was available on the fuel used by individual vessels, it is assumed that heavy fuel oil was being used in all cases; likewise, all auxiliary engines are assumed to be medium-speed diesel engines. No account was available of vessels operating on gas turbines or unconventional diesel-electric arrangements. For Port of Brisbane, which primarily handles containerised and bulk cargo, any such difference is assumed to be negligible (Clarkson, 2015)-an assumption that might not hold true if this study were adapted for a predominantly cruise or naval port:

$L F=0.83 \times\left(\frac{A S}{S S}\right)^{3}$
In the above formula, $L F$ reperesents the load factor, $S S$ depicts the service speed of the vessel, while $A S$ shows the actual speed the vessel operates at. In reference to Clarkson (2015), for auxilarry enginess, the load factors are dependent on the default figure collected from previous studies (SCG, 2005). The information is comprehensively summarised in Table 3 . In order to be able to culculate the engine emmisions, particular factors associated with emissions are needed for each pollutant that is being investigated. This utilises the values recomemded by Clarkson (2015), Goldsworthy and Renilson (2013), due to the fact that they are the most relevant ones in regard to Australian conditions. This is well demonstated in Table 4. As such, Equation 2 proposed by (Corbett et al., 1999) is used to calculate the emissions for auxiliary and main engines:

$$
E=\frac{P \times L F \times A \times E F}{1000}
$$

In this case, $P$ represents the power that is installed in the auxilarty and main engine, $E$ represents the emissions in terms of kilograms, while $A$ is time operation period in that mode. $E F$ further represents the emission factor in $\mathrm{g} /\left(\mathrm{kWh} \mathrm{h}^{-1}\right)$. 
Table 3: Auxiliary load factors used in the emission inventory

\begin{tabular}{llll}
\hline Defined vessel types & Transit aux LF & RSZ aux LF & Berth aux LF \\
\hline Auto Carrier & 0.15 & 0.45 & 0.26 \\
Bulk Carrier & 0.17 & 0.45 & 0.22 \\
Container Ship & 0.13 & 0.45 & 0.18 \\
Cruise Ship & 0.32 & 0.32 & 0.32 \\
General Cargo Ship & 0.17 & 0.45 & 0.22 \\
Miscellaneous & 0.17 & 0.45 & 0.22 \\
Navy Vessel & 0.32 & 0.32 & 0.32 \\
Reefer & 0.15 & 0.45 & 0.32 \\
RO-RO & 0.15 & 0.45 & 0.30 \\
Tanker & 0.24 & 0.33 & 0.26 \\
\hline
\end{tabular}

Table 4: Emission factors expressed in $\mathrm{g} / \mathrm{kWh}$

\begin{tabular}{llllllllllll}
\hline Engine type & $\mathrm{BSFC}$ & $\mathrm{NO}_{\mathrm{x}}$ & \multicolumn{1}{c}{$\mathrm{SO}_{\mathrm{x}}$} & $\mathrm{CO}$ & $\mathrm{CO}_{2}$ & $\mathrm{PM}_{10.0}$ & $\mathrm{PM}_{2.5}$ & $\mathrm{VOC}$ & $\mathrm{HC}$ & $\mathrm{N}_{2} \mathrm{O}$ & $\mathrm{CH}_{4}$ \\
\hline Main (SSD) & 195 & 18.1 & 10.30 & 0.5 & 622 & 1.42 & 1.31 & 0.3 & 0.69 & 0.031 & 0.006 \\
Main (MSD) & 205 & 13.2 & 2.00 & 1.1 & 654 & 0.31 & 0.29 & 0.2 & 0.65 & 0.031 & 0.004 \\
Aux (MSD) & 217 & 13.9 & 2.12 & 1.1 & 692 & 0.32 & 0.29 & 0.4 & 0.52 & 0.031 & 0.004 \\
Boiler & 305 & 2.1 & 16.10 & 0.2 & 973 & 1.47 & 1.35 & 0.1 & 0.10 & 0.08 & 0.002 \\
\hline
\end{tabular}

Table 5: Surface meteorology stations used in the CALPUFF model

\begin{tabular}{lllllll}
\multicolumn{2}{l}{ Table 5: Surface meteorology stations used in the CALPUFF model } \\
\hline & Station name & Station ID & UTM X $(\mathrm{km})$ & UTM Y $(\mathrm{km})$ & Time zone & $\begin{array}{l}\text { Anemometer } \\
\text { height }(\mathrm{m})\end{array}$ \\
Station name (full) & YAMB & 40004 & 471.498 & 6943.783 & UTC+1000 & 10 \\
AMBERLEY AMO & CPMN & 40043 & 546.232 & 7010.001 & UTC+1000 & 10 \\
CAPE MORETON LIGHTHOUSE & YBAF & 40211 & 500.770 & 6950.241 & UTC+1000 & 10 \\
ARCHERFIELD AIRPORT & YBBN & 40842 & 512.774 & 6970.173 & UTC+1000 & 10 \\
BRISBANE AERO & BRIS & 40913 & 503.843 & 6960.309 & UTC+1000 & 10 \\
BRISBANE & MBPS & 40925 & 532.911 & 6954.517 & UTC+1000 & 10 \\
BANANA BANK NORTH BEACON & MBPC & 40926 & 523.924 & 6984.334 & UTC+1000 & 10 \\
INNER RECIPROCAL MARKER & MBPN & 40927 & 526.420 & 7008.209 & UTC+1000 & 10 \\
SPITFIRE CHANNEL BEACON & REDC & 40958 & 509.130 & 6989.537 & UTC+1000 & 10 \\
REDCLIFFE & & & & & &
\end{tabular}

\section{CALPUFF Modelling: Modelling Domain and Time Period}

The modelling domain chosen for the model is a $100 \times 100 \mathrm{~km}$ grid with $1 \mathrm{~km}$ grid spacing. The domain is centred at the Bureau of Meteorology (BoM), Brisbane Aero monitoring station considering the coordinates for the domain corners. Note that CALPUFF requires all coordinates to be input in universal transverse Mercator format. The modelling period is the full 2013 calendar year from 1 January 2013 00:00 to 1 January 2014 00:00.

Applying a contour plot of land-use categories over the modelling domain, land-use data for Australia is from NOAA (2017). This data set covers all of Australia and can be used for setting up models at other sites in Australia. Elevation data for the modelling domain is from the Shuttle Radar Topography Mission (USGS, 2017). This also includes a contour plot of terrain elevation over the modelling domain. Coastline data for Australia is from the Global Self-consistent Hierarchical High-resolution Geography Database (NOAA, 2017). Surface meteorological data, from the BoM monitoring stations, as well as Precipitation and Upper air data are listed in Table 5 and shown in Fig. 1.
The missing soundings have been repaired by manually substituting upper air data modelled using the fifth-generation Penn State/NCAR Mesoscale Model (2017). For modelling sites in Australia, local upper air data must be purchased and repaired if necessary. If no suitable data are available, then 3D gridded prognostic data can be purchased instead. Overwater meteorological parameters have instead been modelled using CALMET with the Initial Guess overwater meteorology initialised based on the available upper air data. 3D gridded prognostic wind data is not included in the model because suitable observational upper air data (comprehensive data) is available from the Brisbane Aero meteorological monitoring station. For other locations in Australia, it may be necessary to include $3 \mathrm{D}$ gridded prognostic data if upper air data is unavailable.

Ten sources were modelled in the CALPUFF model, as summarised in Table 6 and shown in Fig. 2. Threepoint sources were positioned at the centre of the berths at Luggage Point, QLC Wharf and Viva Energy Wharf, corresponding to emissions from vessels in port (at berth). A second set of four-point sources extended from the berths to Fisherman Islands, Caltex Tanker Wharf, Pinkenba Bulk Terminal and Hamilton 
Wharves, corresponding to emissions while entering the port, manoeuvring. The last three-point sources match the navigation of ships while in transit near the pilot boarding ground, in Moreton Bay and near Dunwich. A stack height of $20 \mathrm{~m}$ and diameter of $0.8 \mathrm{~m}$ is assumed for all vessels; and an exit velocity of $25 \mathrm{~m} / \mathrm{s}$ at $539.6 \mathrm{~K}$ is modelled.
A sample wind rose plot at 517.499 UTM X (km), 6972.094 UTM Y $(\mathrm{km})$ where the Fisherman Islands source is located, is shown in Fig. 3. During the one-year period analysed, winds typically blew along different axes, including SSW to NNE (\%10) and S to N (\%10) in total. The winds were stronger and more prevalent in the $\mathrm{SSW}$ direction. Wind speeds varied from 1.8 to $10 \mathrm{~ms}^{-1}$.

Table 6: Sources used in the CALPUFF model (Emission rates in $\mathrm{g} / \mathrm{s}$ )

\begin{tabular}{|c|c|c|c|c|c|c|c|c|}
\hline $\begin{array}{l}\text { Source } \\
\text { numbers }\end{array}$ & Source name & $\begin{array}{l}\text { UTM X } \\
(\mathrm{km})\end{array}$ & $\begin{array}{l}\text { UTM Y } \\
(\mathrm{km})\end{array}$ & $\mathrm{SO}_{2}$ & $\mathrm{NO}_{2}$ & $\mathrm{CO}$ & $\mathrm{PM}_{10.0}$ & $\mathrm{PM}_{2.5}$ \\
\hline 1 & Pilot Boarding Ground & 520.475 & 7001.062 & 33.43 & 53.80 & 4.30 & 4.70 & 4.57 \\
\hline 2 & Moreton Bay & 525.721 & 6987.281 & 33.43 & 53.80 & 4.30 & 4.70 & 4.57 \\
\hline 3 & Dunwich & 533.788 & 6954.203 & 33.43 & 53.80 & 4.30 & 4.70 & 4.57 \\
\hline 4 & Fisherman Islands & 517.499 & 6972.094 & 32.44 & 40.63 & 3.21 & 3.78 & 3.67 \\
\hline 5 & Caltex Tanker Wharf & 515.651 & 6967.705 & 32.44 & 40.63 & 3.21 & 3.78 & 3.67 \\
\hline 6 & Luggage Point & 514.814 & 6969.871 & 31.46 & 27.46 & 2.12 & 2.85 & 2.76 \\
\hline 7 & QLC Wharf & 513.449 & 6967.051 & 31.46 & 27.46 & 2.12 & 2.85 & 2.76 \\
\hline 8 & Viva Energy Wharf & 508.618 & 6964.238 & 31.46 & 27.46 & 2.12 & 2.85 & 2.76 \\
\hline 9 & Pinkenba Bulk Terminal & 507.133 & 6964.062 & 32.44 & 40.63 & 3.21 & 3.78 & 3.67 \\
\hline 10 & Hamilton Wharves & 504.879 & 6964.804 & 32.44 & 40.63 & 3.21 & 3.78 & 3.67 \\
\hline
\end{tabular}

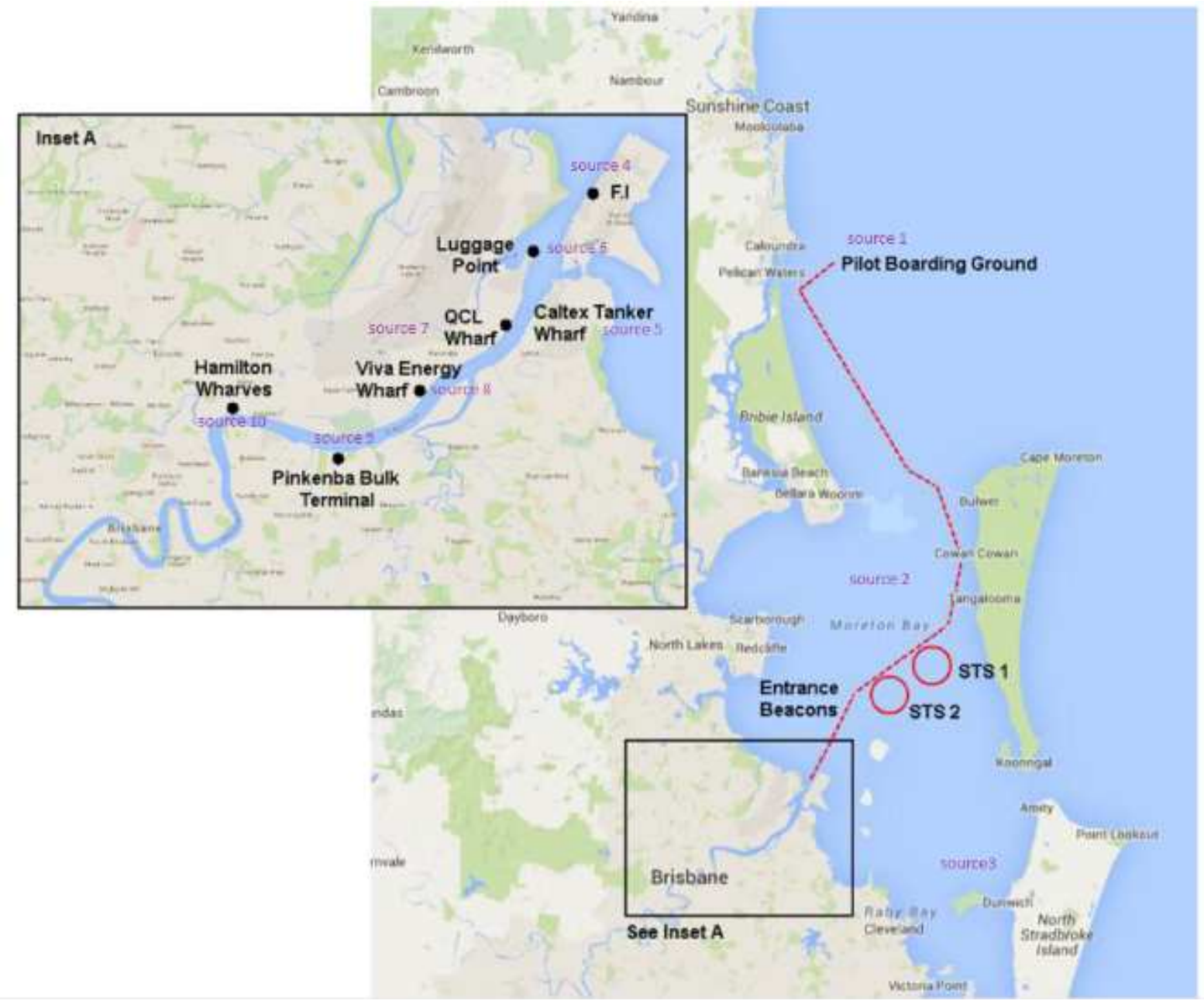

Fig. 2: Sources used in the CALPUFF model 


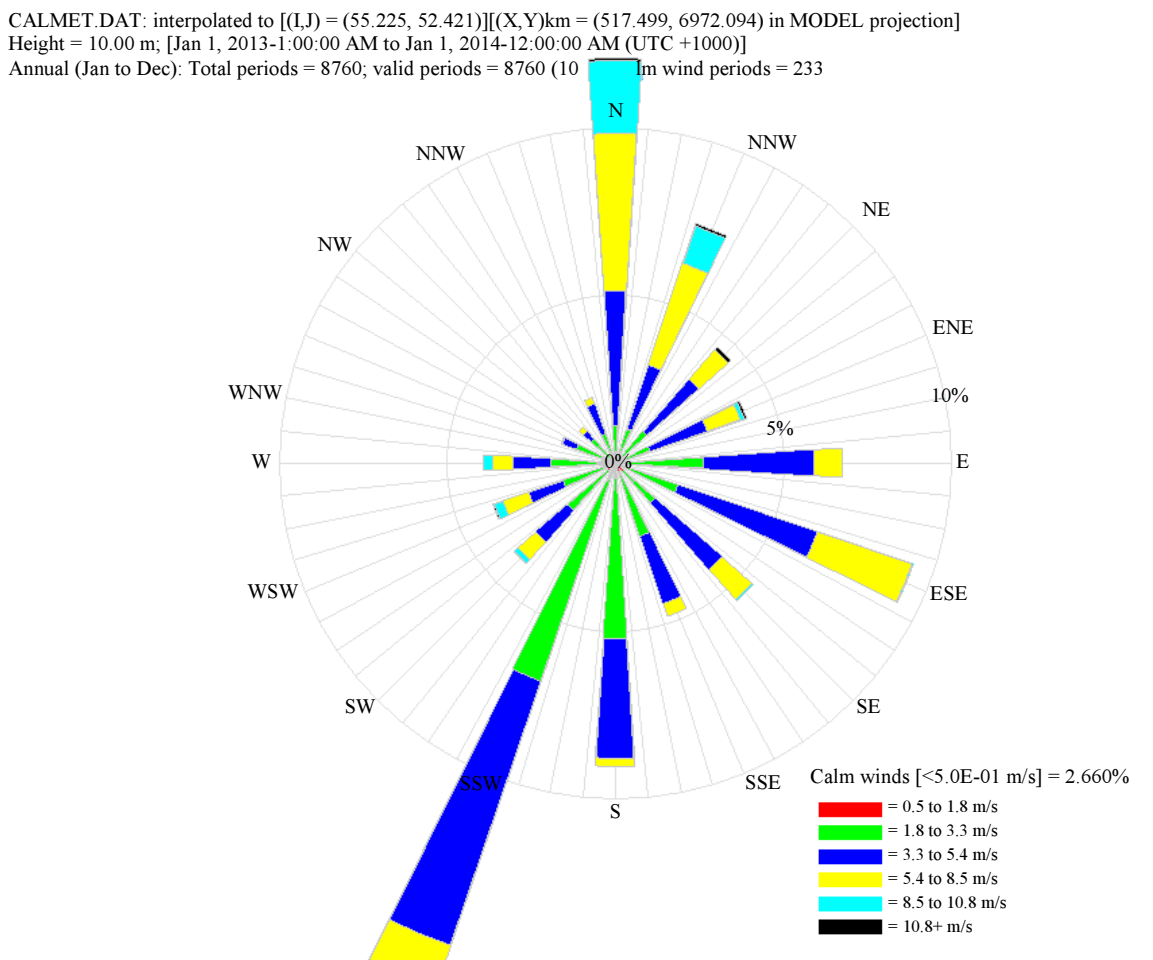

Fig. 3: Wind rose plots at Fisherman Islands location (517.499 UTM X (km), 6972.094 UTM Y (km)

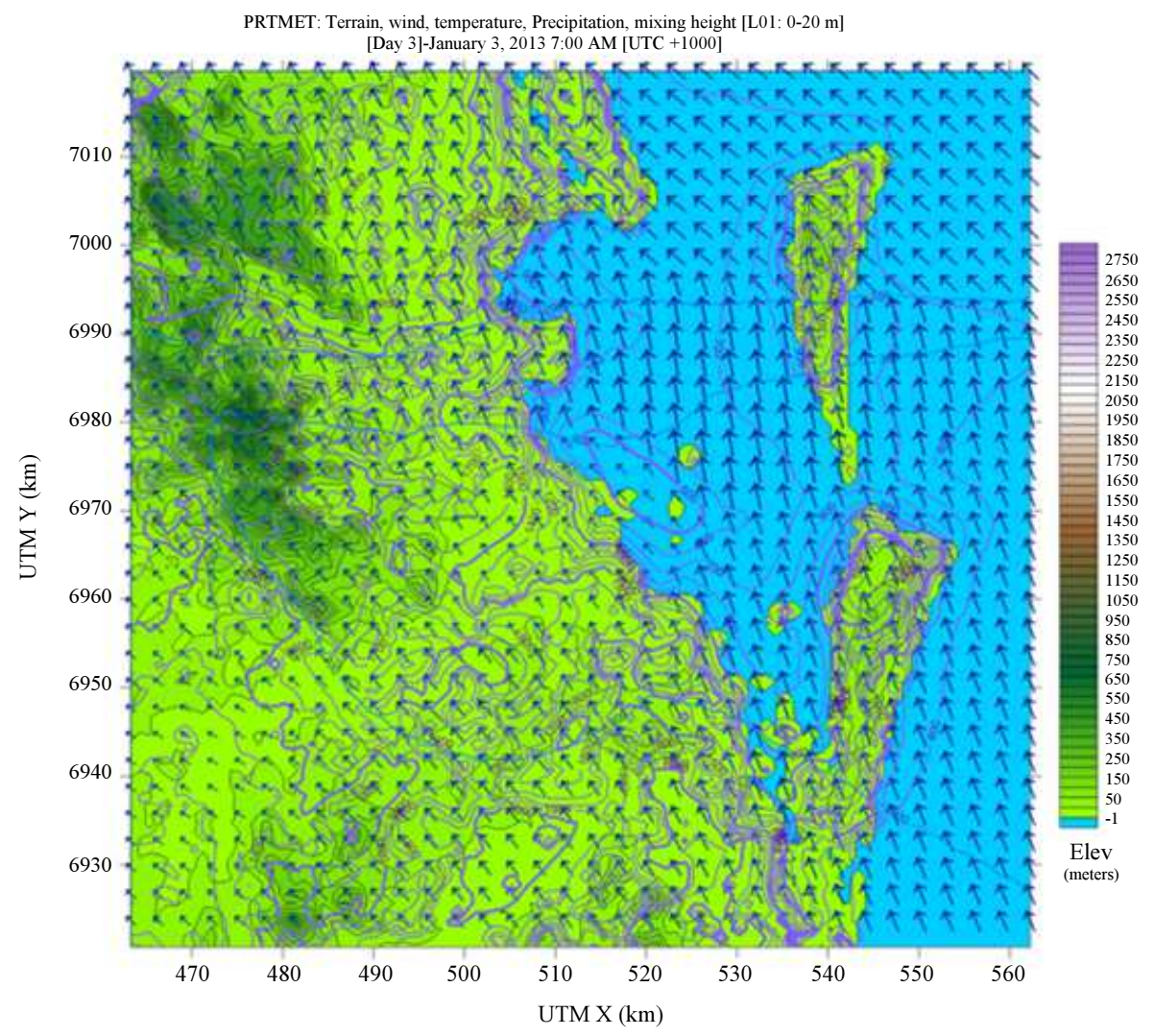

(a) 


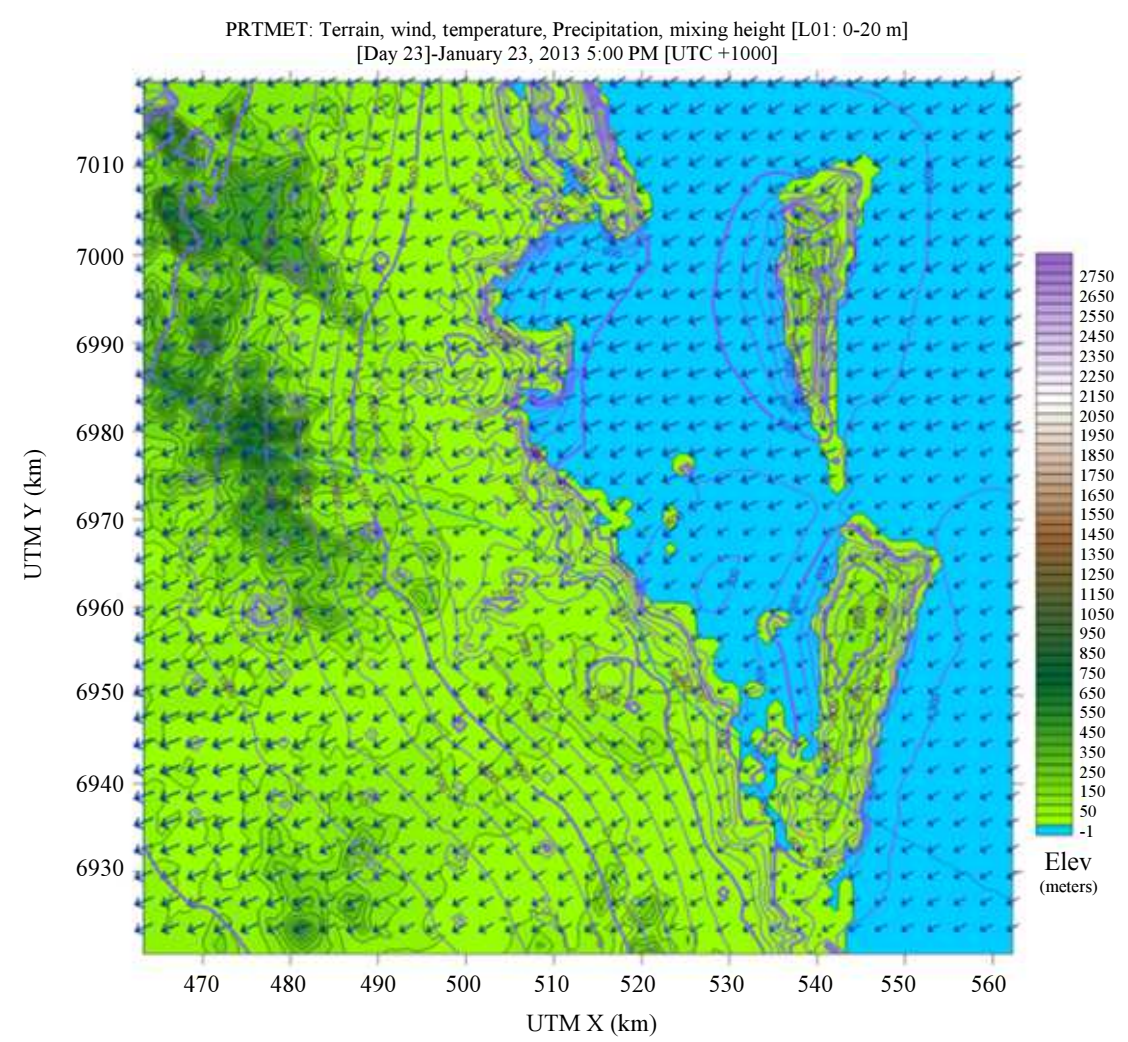

(b)

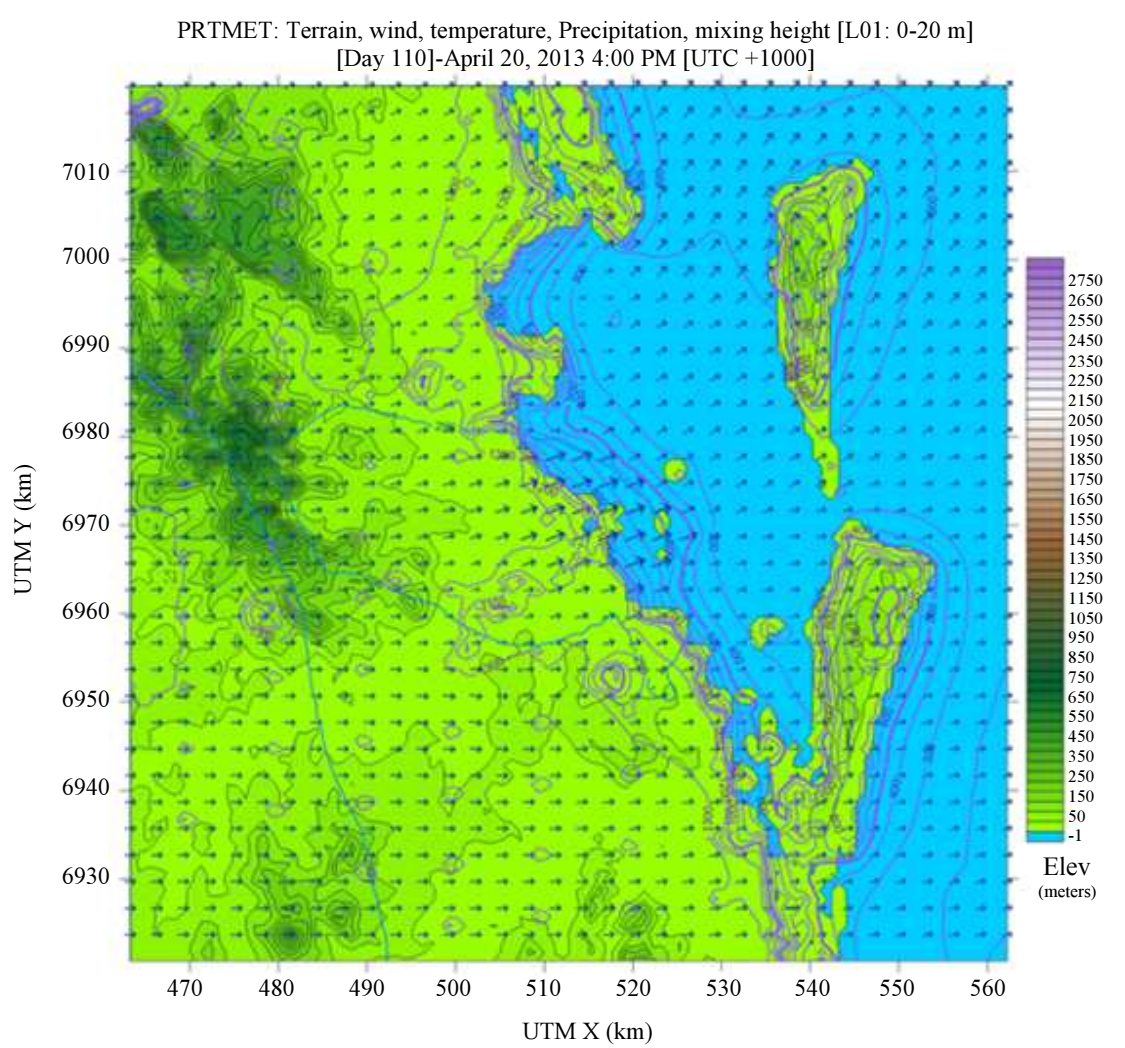

(c) 


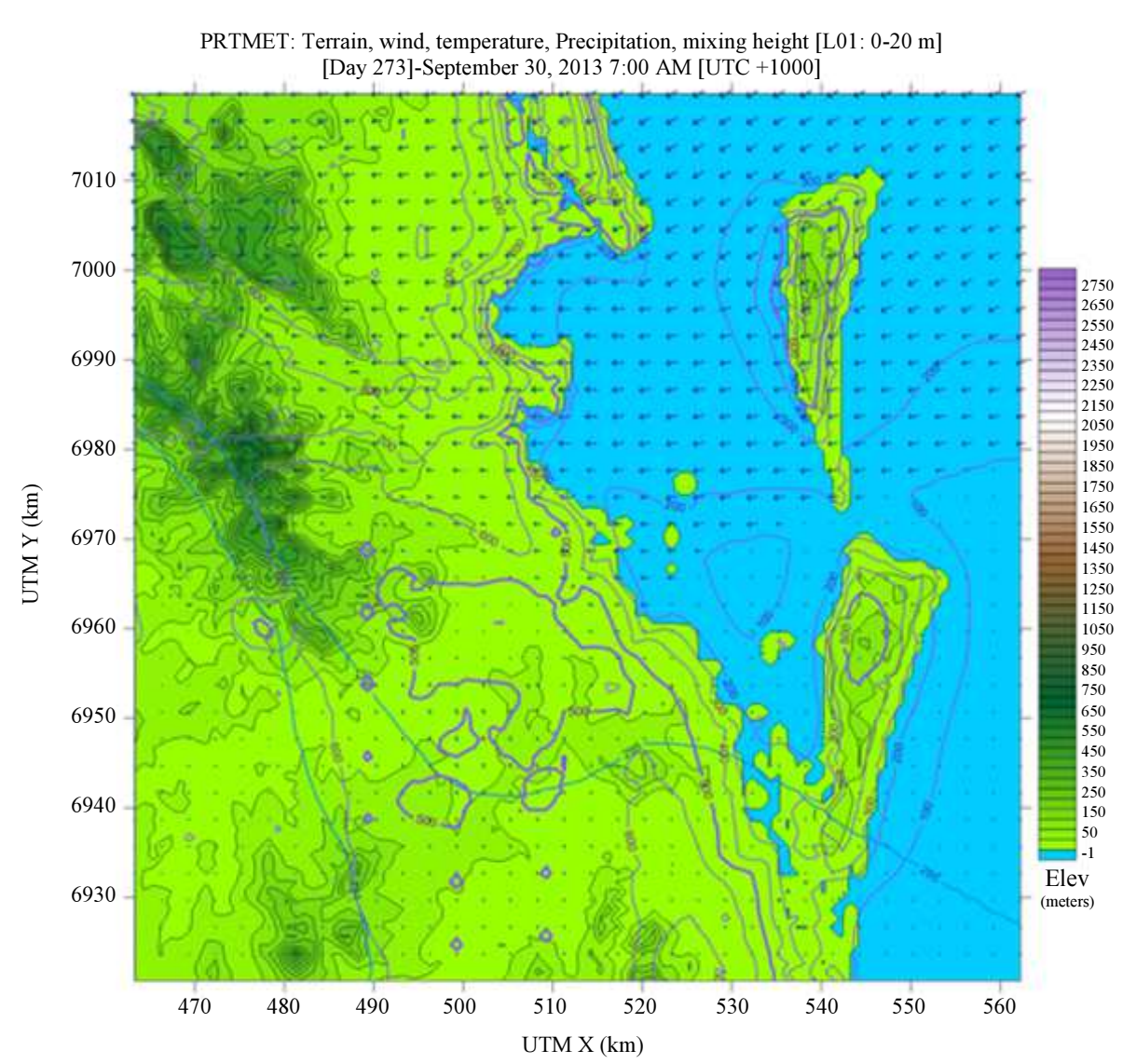

(d)

Fig. 4: Sample wind fields, precipitation and mixing heights across the domain from 0000 January 12013 to 0000 January 12014 ;

(a) Variances in Day 3 (b) Variances in Day 23 (c) Variances in Day 110 (d) Variances in Day 273

Figure 4 also shows the variances in the flow around the entire model and in particular close to the chosen sources at some arbitrary chosen times. Over the year modelled, the effect of the coast on the meteorology is quite distinct. The diurnal temperature changes and corresponding shifts in wind direction, precipitation and mixing height can be seen to cause confused flow around source points. These flows confirm the need for the more advanced modelling capabilities of CALPUFF. In addition they demonstrate representative domain conditions using observational data, while sufficient data on surface stations are also available.

\section{Results and Discussion}

The averaged ground level concentrations of $\mathrm{SO}_{2}$, $\mathrm{NO}_{\mathrm{x}}, \mathrm{CO}$ and $\mathrm{PM}_{2.5}$ over a year were calculated using CALPUFF. Concentrations across the whole domain were calculated at the $1 \mathrm{~km}$ spaced gridded receptors. Sample averaged concentration plots of dispersion contour plot are shown below in Fig. 5.

Due to the wide varying wind conditions across the modelling period, dispersion of all pollutants (and deposition of $\mathrm{PM}_{2.5}$ and $\mathrm{PM}_{10.0}$ ) showed different trends. The concentrations represented in the figure are based on the emission rates adapted from the Port of Brisbane emissions inventory. The case study coverage, given the availability of full data, is rigorous enough to draw solid conclusions suggesting there is the potential for further investigation into actual risk estimations on Australian ports and the need to calculate hazard values.

\section{Health Impact Assessment}

Health Impact Assessment includes calculating average concentrations (Fig. 5) across the air shed for the appropriate averaging times and applying the Concentration-Response Function (CRF) provided from a review of the literature (Williams, 2012; Erbas et al., 2005; Jalaludin et al., 2008). This study uses demographic data from the Australian Bureau of Statistics. The levels of contaminants were measured twice: Once with and once without background concentrations. This was to reveal the contribution from ships, which it would be useful to compare with impacts from all sources. Addressing particular health points defined by the CRFs, like mortality due to respiratory failure, is a useful aim (Table 7). 
Considerably, Health Impact Assessment is an internationally recognised policy tool that evaluates and monitors the potential risks and hazards to certain exposure in particular communities. For instance, a comparison of the hazards exposure to the people dwelling near Brisbane port illustrated the importance of Health Impact Assessment. The study further illustrates the vital components needed to effectively identify when and where the health of the public is likely to be affected negatively, and also recommends the interventions which can be applied to reduce such hazards and risks. Furthermore, the research asserts that shipping activities are likely to affect the health of port residents. When the rate of emissions from shipping activites is high, an immediate response is supposed to be initiated to minimise the exposure to those living near ports.

Arguably, this study is just tip of the iceberge regarding what should be done in terms of occupational exposure, exposure scenarios, and relevant pathways in order to foster better comprehension of the impact that primary emissions have on the public health. As such, with a comprehensive Health Impact Assessment, it is quite easy to identify when and where the health of public can be affected. The assessment also assists in developing strategies which can be used to reduce the threshold of the impacts. Irrefutably, the study conducted in the port of Brisbane regarding the significant health risks faced by those living near the port reveals that further study is needed.

\section{Short-term and Long-term Guideline Validation Assessment}

The potential impact on the entire air shed, with pollutant concentrations (Fig. 5) assessed via CALPUFF, are analysed in this section. Averaging times are used as required. Receptors in this case will be:

- The single worst-affected location, not on water, anywhere in the air shed. At this location a comparison against the guidelines for threshold risks and an assessment of carcinogenic risk from diesel particulates, is made.

- Other sensitive receptors of interest, such as schools, kindergartens, hospitals and retirement homes. Data from CALPUFF for those locations have been extracted. Assessment of risks at these locations follows the worst-case location described above.

Table 7: Health endpoints and their reference concentrations

\begin{tabular}{|c|c|c|c|c|c|c|c|}
\hline \multirow[b]{2}{*}{ Health outcomes } & \multicolumn{7}{|c|}{$\mathrm{SO}_{\mathrm{x}}$ Concentration-response function $(95 \% \mathrm{CI})$} \\
\hline & Australian & UK & Europe & US EPA & WHO & Recommended & This study \\
\hline \multicolumn{8}{|c|}{ Long-term outcomes (annual average concentration) } \\
\hline $\begin{array}{l}\text { Change in forced } \\
\text { expiratory volume }\end{array}$ & No effect in single pollutant model. & $\mathrm{n} / \mathrm{a}$ & $\mathrm{n} / \mathrm{a}$ & $\mathrm{n} / \mathrm{a}$ & $\mathrm{n} / \mathrm{a}$ & $\begin{array}{l}\text { CRF: }-6.62 \text { mls }(-12.3 \text { to }-0.96 \mathrm{mls}) \\
\text { per } 0.74 \mathrm{PPb} \text { in } 2 \text { pollutant model } \\
\text { with NO2 (Williams, 2012). }\end{array}$ & $-12.7 \mathrm{mls}$ \\
\hline $\begin{array}{l}\text { Change in forced } \\
\text { vital capacity }\end{array}$ & No effect in single pollutant model. & & & & & $\begin{array}{l}\text { CRF: }-8.92 \mathrm{mls}(-16.0 \text { to }-1.84 \mathrm{mls}) \\
\text { per } 0.74 \mathrm{PPb} \text { in } 2 \text { pollutant model } \\
\text { with } \mathrm{NO}_{2} \text { (Williams, 2012). }\end{array}$ & $-17.1 \mathrm{mls}$ \\
\hline \multicolumn{8}{|c|}{ Emergency department visits } \\
\hline Asthma & $\begin{array}{l}\text { Not assessed. (Erbas et al., } \\
\text { 2005) }\end{array}$ & $\mathrm{n} / \mathrm{a}$ & $\mathrm{n} / \mathrm{a}$ & $\mathrm{n} / \mathrm{a}$ & $\mathrm{n} / \mathrm{a}$ & $\begin{array}{l}\text { CRF: } 1.6 \%(0.72 .4 \%) \text { per } 0.8 \mathrm{PPb} \\
\text { (Jalaludin et al., 2008). }\end{array}$ & $7.53 \%$ \\
\hline \multicolumn{8}{|c|}{ Incidence of myocardial infarction (heart attacks) } \\
\hline Bronchodilator use & $\begin{array}{l}\text { 1-hour maximum Night use: } 1.0247 \\
\text { (1.0021-1.0478) per } 1 \mathrm{PPb} \\
\text { (Williams, 2012)- } \\
\text { Adelaide, Brisbane, }\end{array}$ & $\mathrm{n} / \mathrm{a}$ & $\mathrm{n} / \mathrm{a}$ & $\mathrm{n} / \mathrm{a}$ & $\mathrm{n} / \mathrm{a}$ & $\begin{array}{l}\text { CRF for night bronchodilator use: } \\
1.0247(1.0021-1.0478) \text { per } 1 \mathrm{PPb} \\
\text { from Williams (2012). }\end{array}$ & 3.86 \\
\hline
\end{tabular}

Table 8: Maximum Concentrations $\left(\mu \mathrm{g} / \mathrm{m}^{3}\right)$ versus available guidelines

\begin{tabular}{|c|c|c|c|c|}
\hline Pollutants & Averaging time & Concentrations & NEPM & WHO \\
\hline $\mathrm{CO}$ & $10 \mathrm{~min}$ & 1.87 & $\mathrm{n} / \mathrm{a}$ & $100000 \mathrm{ug} / \mathrm{m}^{3}$ \\
\hline $\mathrm{CO}$ & $30 \mathrm{~min}$ & 5.83 & $\mathrm{n} / \mathrm{a}$ & $60000 \mathrm{ug} / \mathrm{m}^{3}$ \\
\hline $\mathrm{CO}$ & $1 \mathrm{~h}$ & 48.60 & $\mathrm{n} / \mathrm{a}$ & $30000 \mathrm{ug} / \mathrm{m}^{3}$ \\
\hline $\mathrm{CO}$ & $8 \mathrm{~h}$ & 22.30 & 9 PPm & $10000 \mathrm{ug} / \mathrm{m}^{3}$ \\
\hline $\mathrm{SO}_{2}$ & $10 \mathrm{~min}$ & 15.70 & $\mathrm{n} / \mathrm{a}$ & $500 \mathrm{ug} / \mathrm{m}^{3}$ \\
\hline $\mathrm{SO}_{2}$ & $1 \mathrm{~h}$ & 93.80 & $0.2 \mathrm{PPm}$ & $\mathrm{n} / \mathrm{a}$ \\
\hline $\mathrm{SO}_{2}$ & $24 \mathrm{~h}$ & 36.20 & $0.08 \mathrm{PPm}$ & $20 \mathrm{ug} / \mathrm{m}^{3}$ \\
\hline $\mathrm{SO}_{2}$ & 1 year & 9.98 & $0.02 \mathrm{PPm}$ & $\mathrm{n} / \mathrm{a}$ \\
\hline $\mathrm{NO}_{2}$ & $1 \mathrm{~h}$ & 25.30 & $0.12 \mathrm{PPm}$ & $200 \mathrm{ug} / \mathrm{m}^{3}$ \\
\hline $\mathrm{NO}_{2}$ & 1 year & 10.40 & $0.03 \mathrm{PPm}$ & $40 \mathrm{ug} / \mathrm{m}^{3}$ \\
\hline $\mathrm{PM}_{10.0}$ & $24 \mathrm{~h}$ & 64.20 & $50 \mathrm{ug} / \mathrm{m}^{3}$ & $50 \mathrm{ug} / \mathrm{m}^{3}$ \\
\hline $\mathrm{PM}_{10.0}$ & 1 year & 8.30 & $25 \mathrm{ug} / \mathrm{m}^{3}$ & $20 \mathrm{ug} / \mathrm{m}^{3}$ \\
\hline $\mathrm{PM}_{2.5}$ & $24 \mathrm{~h}$ & 40.30 & $25 \mathrm{ug} / \mathrm{m}^{3}$ & $25 \mathrm{ug} / \mathrm{m}^{3}$ \\
\hline $\mathrm{PM}_{2.5}$ & 1 year & 8.50 & $8 \mathrm{ug} / \mathrm{m}^{3}$ & $10 \mathrm{ug} / \mathrm{m}^{3}$ \\
\hline
\end{tabular}


Plotting: Terrain, wind, temperature, Precipitation, $\mathrm{SO}_{2}$-24HR concentration [L01: 0-20 m] [Day 4]-January 4, 2013 12:00 AM [UTC +1000]

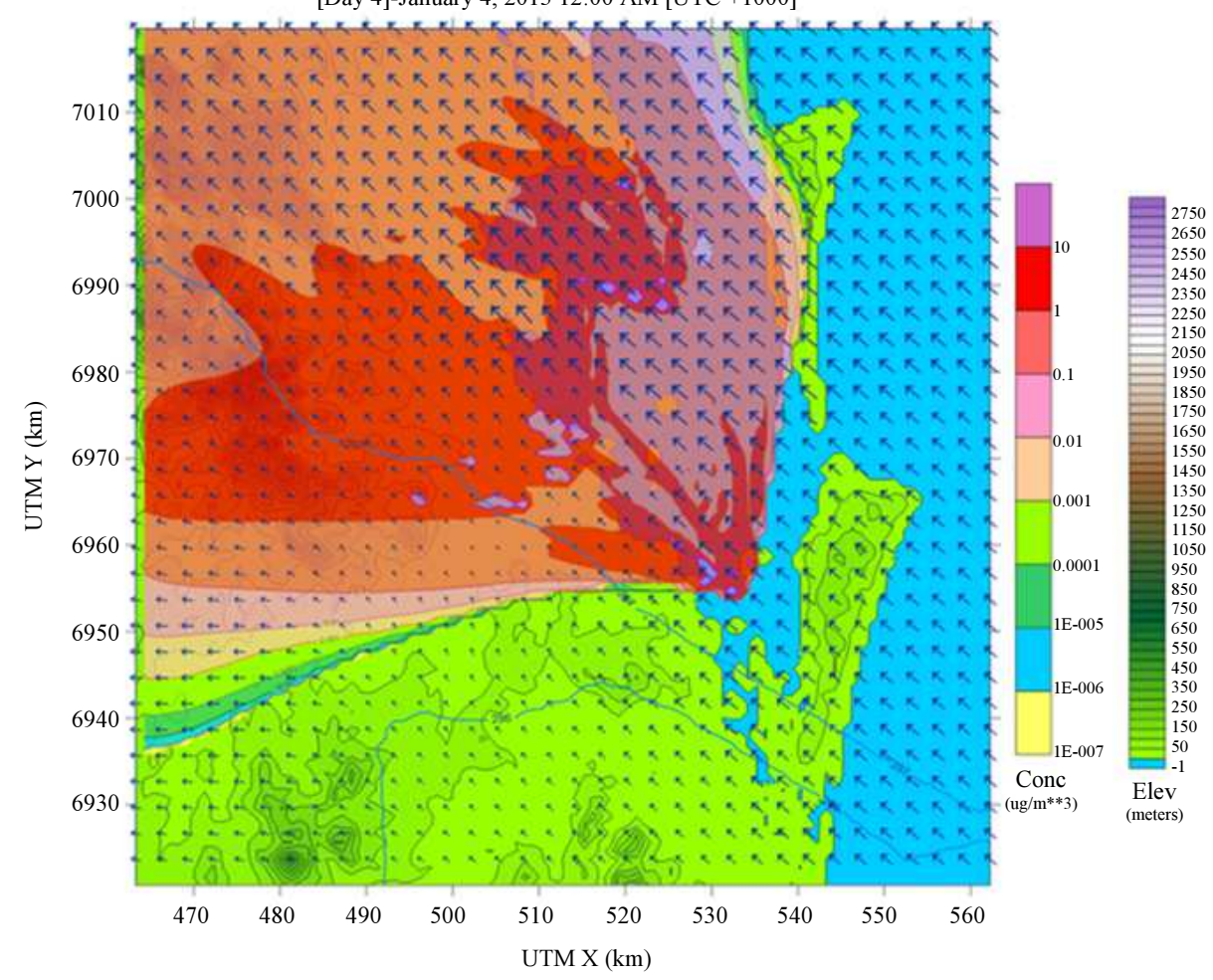

(a)

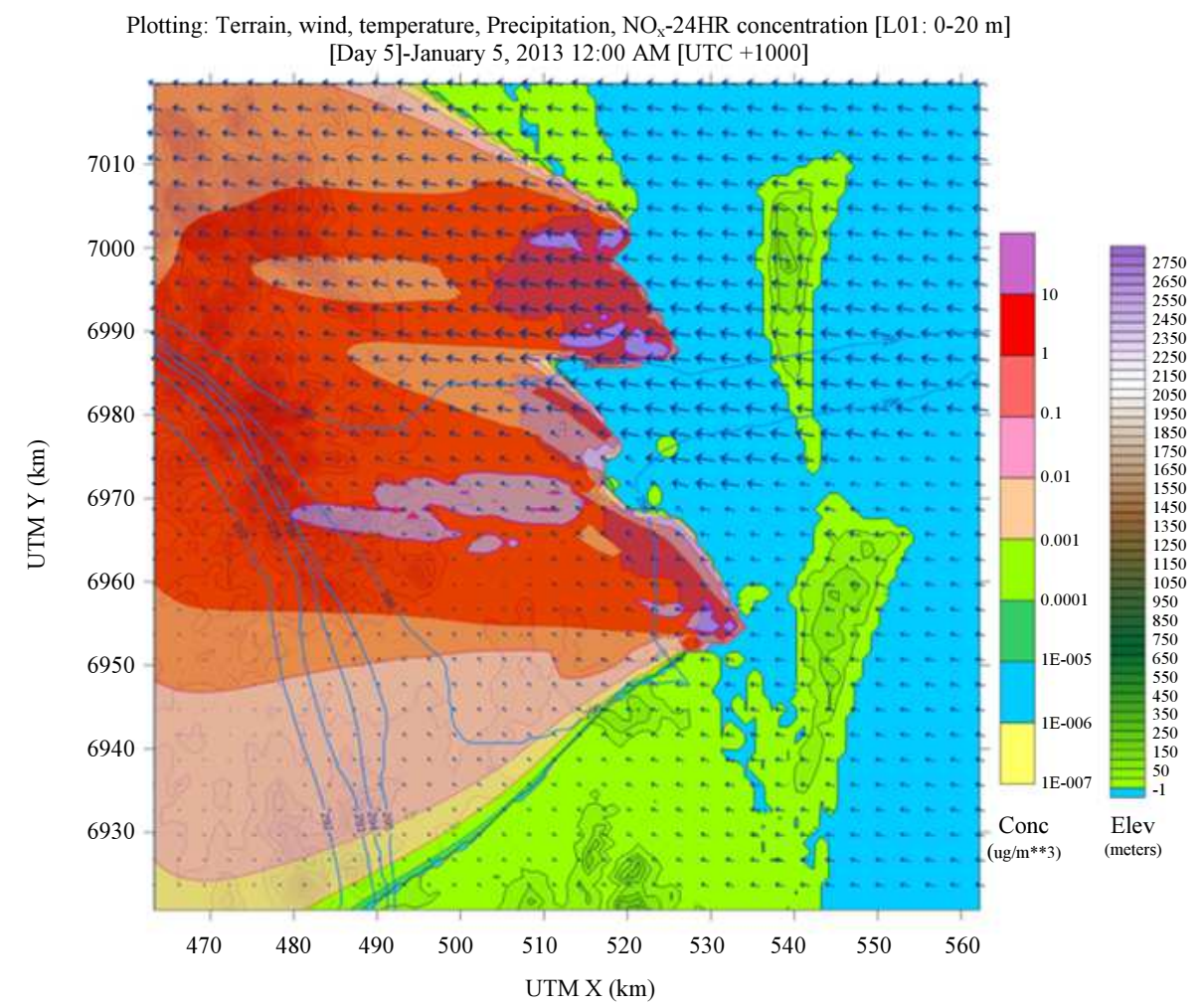

(b) 


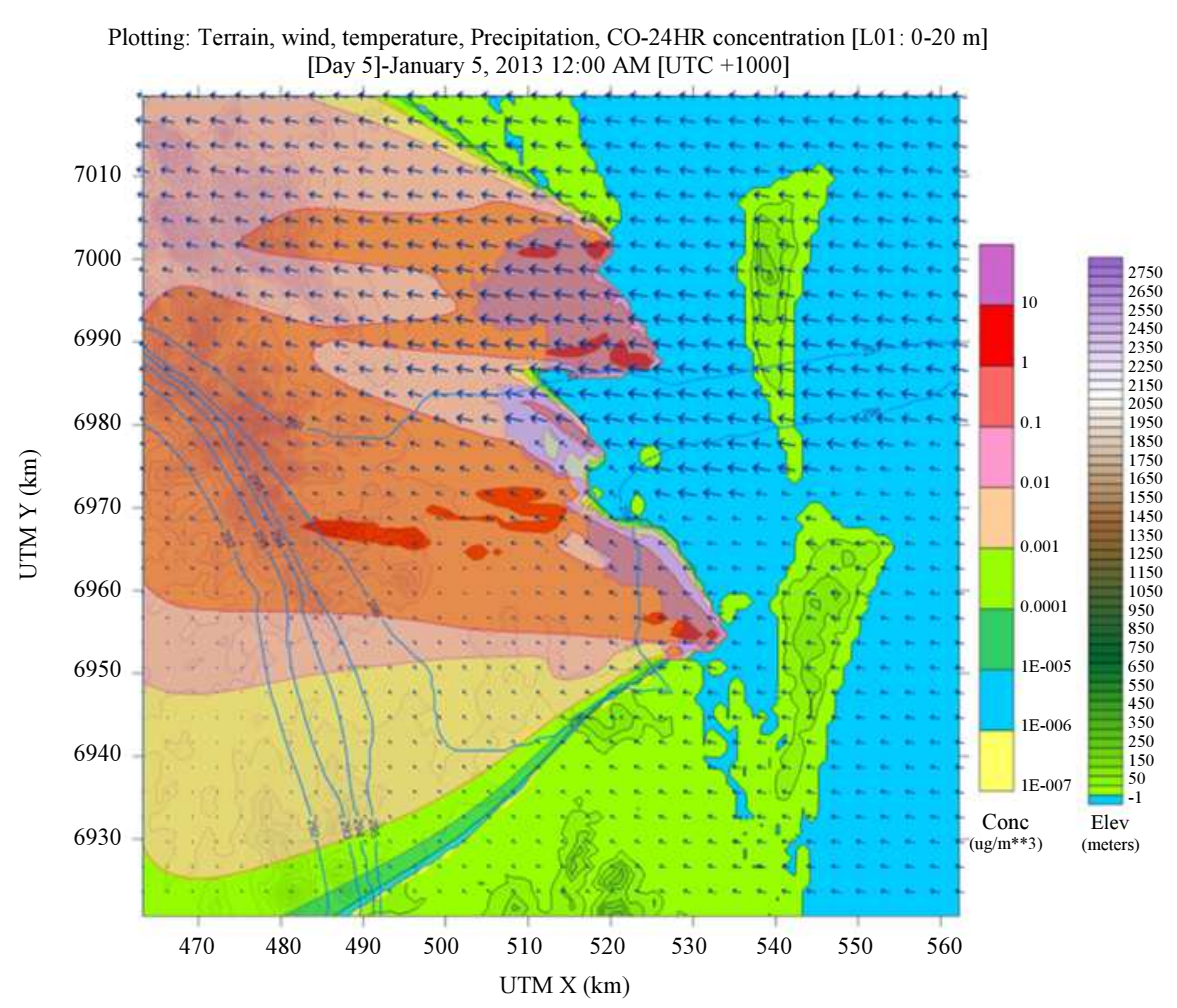

(c)

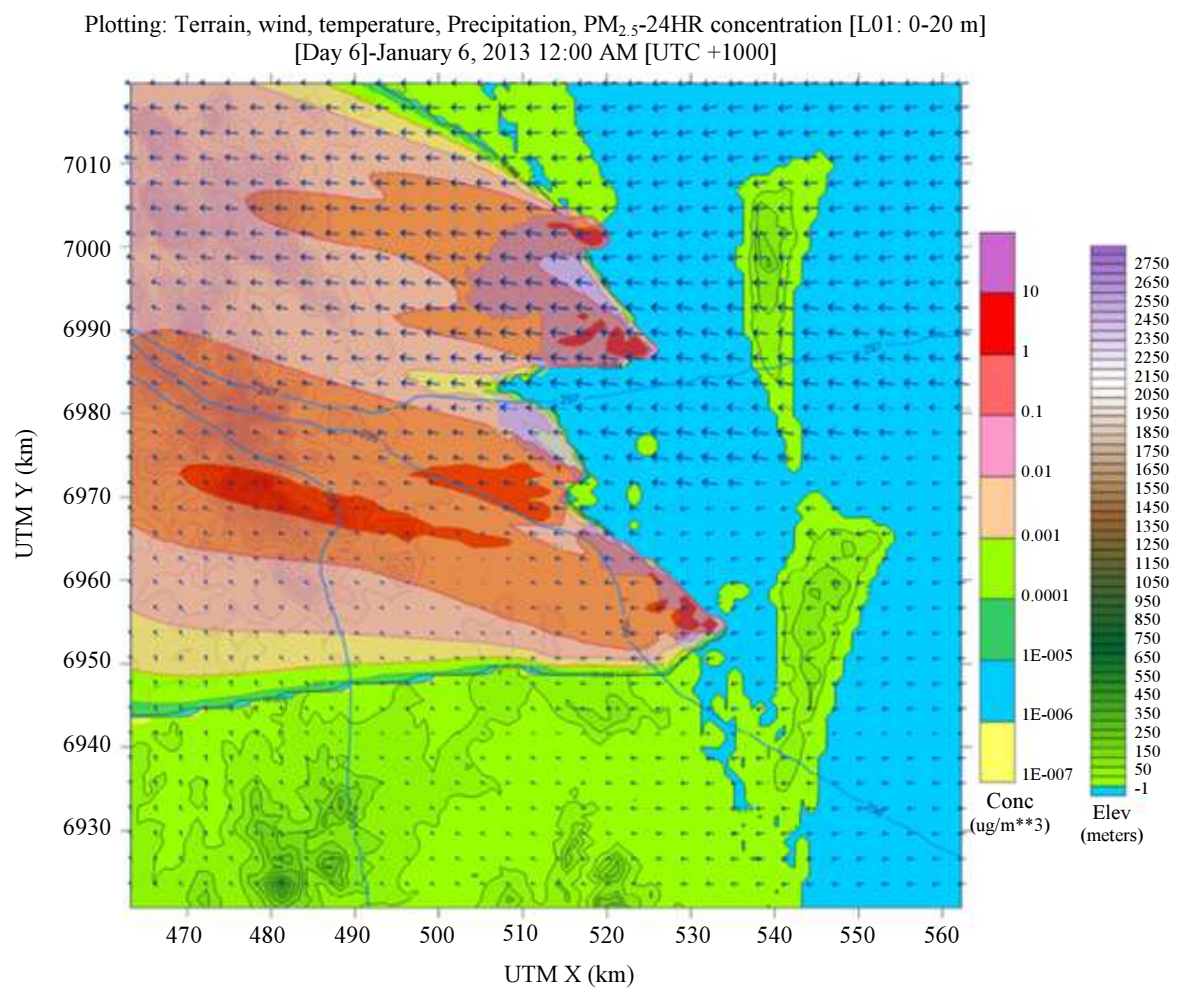

(d)

Fig. 5: Sample averaged concentration plot of $\mathrm{SO}_{2}, \mathrm{NO}_{x}, \mathrm{CO}$ and $\mathrm{PM}_{2.5}$; (a) Concentration plot of $\mathrm{SO}_{2}$; (b) Concentration plot of $\mathrm{NO}_{\mathrm{x}}$; (c) Concentration plot of $\mathrm{CO}$; (d) Concentration plot of $\mathrm{PM}_{2.5}$ 
Table 9: Average Concentrations $\left(\mu \mathrm{g} / \mathrm{m}^{3}\right)$ versus available guidelines

\begin{tabular}{lllll}
\hline Pollutant & Averaging time & Concentrations & NEPM & WHO \\
\hline $\mathrm{CO}$ & $10 \mathrm{~min}$ & 0.96 & $\mathrm{n} / \mathrm{a}$ & $100000 \mathrm{ug} / \mathrm{m}^{3}$ \\
$\mathrm{CO}$ & $30 \mathrm{~min}$ & 3.25 & $\mathrm{n} / \mathrm{a}$ & $60000 \mathrm{ug} / \mathrm{m}^{3}$ \\
$\mathrm{CO}$ & $1 \mathrm{~h}$ & 28.10 & $\mathrm{n} / \mathrm{a}$ & $30000 \mathrm{ug} / \mathrm{m}^{3}$ \\
$\mathrm{CO}$ & $8 \mathrm{~h}$ & 17.50 & $9 \mathrm{PPm}$ & $10000 \mathrm{ug} / \mathrm{m}^{3}$ \\
$\mathrm{SO}$ & $10 \mathrm{~min}$ & 13.10 & $\mathrm{n} / \mathrm{a}$ & $500 \mathrm{ug} / \mathrm{m}^{3}$ \\
$\mathrm{SO}_{2}$ & $1 \mathrm{~h}$ & 75.80 & $0.2 \mathrm{PPm}$ & $\mathrm{n} / \mathrm{a}$ \\
$\mathrm{SO}_{2}$ & $24 \mathrm{~h}$ & $0.08 \mathrm{PPm}$ & $20 \mathrm{ug} / \mathrm{m}^{3}$ \\
$\mathrm{SO}_{2}$ & 1 year & 19.80 & $0.02 \mathrm{PPm}$ & $\mathrm{n} / \mathrm{a}$ \\
$\mathrm{NO}_{2}$ & $1 \mathrm{~h}$ & 7.50 & $0.12 \mathrm{PPm}$ & $200 \mathrm{ug} / \mathrm{m}^{3}$ \\
$\mathrm{NO}_{2}$ & 1 year & 19.63 & $0.03 \mathrm{PPm}$ & $40 \mathrm{ug} / \mathrm{m}^{3}$ \\
$\mathrm{PM}_{10.0}$ & $24 \mathrm{~h}$ & 9.84 & $50 \mathrm{ug} / \mathrm{m}^{3}$ & $50 \mathrm{ug} / \mathrm{m}^{3}$ \\
$\mathrm{PM}_{10.0}$ & 1 year & 49.70 & $25 \mathrm{ug} / \mathrm{m}^{3}$ & $20 \mathrm{ug} / \mathrm{m}^{3}$ \\
$\mathrm{PM}_{2.5}$ & $24 \mathrm{~h}$ & 6.12 & $25 \mathrm{ug} / \mathrm{m}^{3}$ & $25 \mathrm{ug} / \mathrm{m}^{3}$ \\
$\mathrm{PM}_{2.5}$ & 1 year & 23.74 & $8 \mathrm{ug} / \mathrm{m}^{3}$ & $10 \mathrm{ug} / \mathrm{m}^{2}$ \\
\hline
\end{tabular}

Available guidelines from Australia - NEMP (most relevant locally) (WHO, 2000) and from the World Health Organisation (most applicable on a global scale) WHO (2012) were applied to validate the results against (Table 8 and 9).

In this advanced dispersion modelling, chemically inert emissions have been considered to be transported by advection and diffusion and are deposited on both land and sea. Sea breezes and air flows influenced by landforms, along with other elements relevant to local levels of air contamination, are predicted in our model, set against the 2013 meteorology. It is of paramout importance to have local meteorology as the model predicts. Plume Rise Module (PRM), quality of air utilised in the simulations, and Lagrangian Particle Model (LPM) represents near-source dispersion which is accurate. The worst case approach discusssed, managed to assess the exposure to toxic compounds through inhalation which is caused by the primary emissions.

The model value usually depends on the quality of data to be processed and this is the truth behind integrated emission models and advanced dispersion. If there is inadequacy of available data, excellent results can be acquired using geo statistical models or land use regression, just as the approach used in this study.

\section{Conclusion}

This paper offered a methodology utilising a robust emissions inventory to quantify the emissions of Ocean Going Vessels and incorporating CALPUFF for dispersion modelling. To demonstrate the effectiveness of methodology, it has been applied to Port of Brisbane and returns representative emissions results.

This study highlights the need for any assessment of the dispersion of in-port ship emissions to consider all emissions within port boundaries. This is particularly so in ports like Brisbane where long transit passages take place near densely populated suburbs.

This study demonstrates that applying emission inventory results to detailed dispersion modelling of Port of Brisbane and completing an associated risk assessment provides a convincing demonstration of the need to combat the widespread effects of ship emissions.

With further studies, the existing uncertainities in the present assessment can be reduced regarding the exposure to air emissiions. Moreover, the studies can contribute immensly to directing efforts to curtail the exposure and also effectively address the dispersion modelling limitations. As such, the study may model long-term and short-term esposures and collect relevant data in terms of personal exposure, area and residence with great emphasis on the peak short-term emissions.

Examination of the toxicity of hydrocarbons such as alkanes, and effects of air pollutants on health attributed to primary emissiions is also needed. When this data is combined with local topography and meteorological conditions, a guideleine will be enacted pertaining the mimimum distance between emissions sources, businesees, schools, and homes that is needed to protect the health of humans. Continued evaluation of these results from the ports for a longer period is also prudent. Evaluating longterm developments in the data with regard to both shipping and meteorological traffic fluctuations will also add more insight to the baseline results.

\section{Acknowledgment}

Special thanks to National Centre for Maritime Engineering and Hydrodynamic in Australian Maritime College for their support of this study. The generous cooperation of Port of Brisbane Corporation is as well acknowledged.

\section{Author's Contributions}

Sanaz Jahangiri: She conducted the design of the technique and analysis.

Natalia Nikolova and Kiril Tenekedjiev: Involved in the model development and data analysis. 


\section{Ethics}

The authors declare no conflicts of interest and confirm that the manuscript has been submitted solely to this journal and is not published, in press, or submitted elsewhere.

\section{References}

Bluett, J., N. Gimson, G. Fisher, C. Heydenrych and T. Freeman et al., 2004. Good practice guide for atmospheric dispersion modelling. New Zealand Ministry for the Environment

Browning, L. and K. Bailey, 2006. Current methodologies and best practices for preparing port emission inventories [Internet]. ICF Consulting report to Environmental Protection Agency.

Clarkson, D., 2015. Development of a risk-based methodology to assess the impact of vessel emissions within Australian ports. Australian Maritime College.

Cooper, D.A., 2003. Exhaust emissions from ships at berth. Atmos. Environ., 37: 3817-3830. DOI: $10.1016 / \mathrm{S} 1352-2310(03) 00446-1$

Corbett, J.J., P.S Fischbeck and S.N Pandis, 1999. Global nitrogen and sulfur inventories for oceangoing ships. J. Geophysical Res., 104: 3457-3470. DOI 10.1029/1998JD100040

Environment, D.O.T. 2016. National environment protection (Ambient Air Quality) Measure.

Erbas, B., A.M. Kelly, B. Physick, C. Code and M. Edwards, 2005. Air pollution and childhood asthma emergency hospital admissions: Estimating intracity regional variations. Int. J. Environ. Health Res., 15: 11-20. DOI: 10.1080/09603120400018717

Goldsworthy, L. and B. Goldsworthy, 2015. Modelling of ship engine exhaust emissions in ports and extensive coastal waters based on terrestrial AIS data-an Australian case study. Environ. Model Software 63: 45-60.

DOI: $10.1016 /$ j.envsoft.2014.09.009

Goldsworthy, L. and M. Renilson, 2013. Ship engine exhaust emission estimates for Port of Brisbane. Air Qual. Climate Change, 47: 26-36.

Holmes, N.S and L. Morawska, 2006. The dispersion of particles: An overview of different dispersion models available. Atmos. Environ., 40: 5902-5928. DOI: 10.1016/j.atmosenv.2006.06.003

Hughes, E., 2011. MARPOL annex VI-prevention of air pollution from ships [Internet]. International Marine Organisation.
Jalaludin, B., B. Khalaj, V. Sheppeard and G. Morgan, 2008. Air pollution and ED visits for asthma in Australian children: a case-crossover analysis. Int. Arch. Occup Environ. Health, 81: 967-974.

DOI: 10.1007/s00420-007-0290-0

Jalkanen, J.P., A. Brink, J. Kalli, H. Pettersson and J. Kukkonen et al., 2009. A modelling system for the exhaust emissions of marine traffic and its application in the Baltic Sea area. Atmos. Chem. Phys., 9: 9209-9223.

DOI: 10.5194/acpd-9-15339-2009

Lucialli, P., P. Ugolini and E. Pollini, 2007. Harbour of Ravenna: the contribution of harbour traffic to air quality. Atmos. Environ., 41: 6421-6431. DOI: $10.1016 /$ j.atmosenv.2007.05.003

NOAA, 2017. GSHH-a global self-consistent, hierarchical, high-resolution geography database. NOAA National Centers for Environmental Information.

NSW EPA, 2005. Approved methods for the modelling and assessment of air pollutants in New South Wales. NSW EPA.

PB, 2015. Port of Brisbane. Shipping Handbook.

SCG, 2005. Port of Long Beach inventory of air emissions inventory. SCG.

Scire, J., D. Strimaitis and R. Yamartino, 2000a. A user's guide for the CALPUFF dispersion model [Internet].

Scire, J.S., F. Robe, M. Fernau and R. Yamartino, 2000b. A user's guide for the CALMET meteorological model.

USEPA, 2009. Regulatory impact analysis: Control of emissions of air pollution from category 3 marine diesel engines. USEPA.

USGS, 2017. Shuttle radar topography mission (SRTM) 1 Arc-second global. USGS.

WHO, 2000. Air quality guidelines. WHO.

WHO, 2012. Diesel engine exhaust carcinogenic. WHO.

Williams, G.E.A., 2012. Australian Child Health and Air Pollution Study (ACHAPS) final report. University of Queensland: National Environment Protection Council.

Winebrake, J.J., J.J Corbett, E.H Green, A. Lauer and V. Eyring, 2009. Mitigating the health impacts of pollution from oceangoing shipping: An assessment of low-sulfur fuel mandates. Environ. Sci. Technol., 43: 4776-4782. DOI: 10.1021/es803224q 